\title{
MEASURING CUSTOMER SATISFACTION AND LOYALTY IN SPA COMPANIES
}

\author{
Eliška Vildová, David Martinčík, Jan Tlučhoř, Dagmar Jakubíková
}

\section{Introduction}

The question of customer satisfaction became one of the central themes of marketing in the late 1970s. One of the reasons was and has been the growing importance of services with a marked shift towards increasing quality. This is evident in the development of selected economic indicators, as well as by analyses of the contribution of services. Presentday customers are more informed, they are becoming more emancipated and demanding, and they want to receive first-rate services, i.e. services that fully meet their requirements. The needs and requirements of every tourism participant change over time depending on their health condition. Spa tourism represents a special form of convalescence with emphasis on health and preventive care.

The development of spa tourism is preconditioned by the existence of natural healing resources (i.e. natural healing waters, gases, bog and climate) that affect the focus of spa treatment. Grounded on the exploitation of natural healing resources, spa treatment is combined with medicamentous therapy, diet therapy, and rehabilitation. Spa treatment is aimed at disease prevention, health improvement and, consequently, at reducing the incapacity for work of the population.

As of June 2013, there were 37 spa locations on the territory of the Czech Republic, operated by $90 \mathrm{spa}$ entrepreneurial entities with the total number of 27,000 beds [4]. At present, these spa companies offer a wide portfolio of services - medical, therapeutic and rehabilitation care, wellness services and hotel accommodation. According to the Czech law, no. 48/1997 medical rehabilitation care (spa care) is provided as indispensable part of medical (healing) process. The law divides two types of medical rehabilitation care, which are covered by public health insurance and has to be allowed from inspection doctor of the health insurance company: (1) comprehensive spa medical rehabilitation care (further referred as comprehensive spa care) and (2) contributory spa rehabilitation care (further referred as contributory spa care - treatment is covered from public health insurance funds while accommodation and boarding is paid by the client). The main difference is in the level of health insurance contribution to the cost of the spa care. Historically this kind of spa care has been typical and prevailing for most Czech spa locations and it's granted to Czech citizens only. Beyond this system of spa care there are other clients of spa companies, so called self-payers (they are accepting the system of medical spa care, but they finance their stay by themselves or better to say not from the Czech public health insurance system), Usually such spa care stays are long-term stays (at least 14 days). We can also find another groups of customers in spa hotels - e.g. regular hotel guests (no use of spa facilities), wellness guests (short stays, some use of spa facilities and service).

This article focuses on such spa companies, which are offering their services to a wide range of domestic and foreign guests. Their sales are no longer only dependent on stays within the comprehensive and contributory spa care segment. Nowadays, they are tourism-oriented enterprises, which don't focus on a single target group. They are dealing with diverse customer segments - domestic and foreign and to foster their business success they need to understand diversity or diversification, which stem from the naturally present differences in the human society. Communication is often influenced by prejudice and individual cultural differences, and when not understood properly, the achievement of the desired business success tends to be quite difficult. [6]

In 2012, the regulation of Department 
(Ministry) of Health of Czech Republic no. 267/2012 limited spa medical rehabilitation care covered from public health insurance. For example, in comparison to previous regulation from 1997, the length of comprehensive spa care has been limited from 28 to 21 paid days, the length of contributory spa rehabilitation care has been limited from 21 to 14 paid days, some medical indications have been deleted from the list of paid spa care etc. This change affected Czech spa companies greatly. For example, during the first 6 months of 2013 , there was a decrease in recommended spa care by $37 \%$ compared to 2012 . In the course of 2012, spa care had already been gradually limited in the light of the changes that were to be introduced. If we look at a comparison with 2010, it is obvious that comprehensive spa care experienced a $43 \%$ drop and contributory spa care a $30 \%$ drop, compared to 2013 . This drop in spa care covered by public health insurance is extreme. Most spa companies had to undergo rapid changes in promotion, target group orientation, and in general, they had to change the product structure and service offer. [1] Recently, The Constitutional Court of the Czech Republic limited the legal force of the Regulation no. 267/2012 to the end of 2014 and an actualization of the law no. 48/1997 is being prepared. This new regulation should partially restore the situation valid before 2012 .

The importance of balneology as a part of the tourism industry is of considerable significance for the Czech Republic. The tourism industry GDP share was 2.7\% in 2011. In the same year, the number of people employed in the industry amounted to 231,266 , which represents $4.56 \%$ of the total number of employees. The number of guests staying at mass accommodation tourist facilities amounted to 12.9 million in $2011,706,838$ of whom were accommodated at spa facilities, i.e. $5 \%$ of all visitors. Measured in bed nights $(38,235,088$ in all accommodation facilities, $6,857,724$ in spa facilities), the share amounts to almost $18 \%$ [21]. Balneology is therefore of vital importance for tourism in the Czech Republic. The company under review provides services in West Bohemia, namely in the Region of Karlovy Vary. In 2011, the Region of Karlovy Vary received 709,733 guests, 426,976 of whom were accommodated at spa facilities. Spa guests make up approx. $60 \%$ of the total number of visitors and they are thus of substantial relevance for the region.
1. Customer Satisfaction and Loyalty

Building customer loyalty and fidelity has always been a priority for balneology and it has become one of the fundamental traits of present-day modern marketing. Quality, customer services, as well as other marketing activities form one complex. Relationship marketing strives to interconnect all these elements and to combine them to achieve a synergic effect. Kotler and Keller [15] see the relationship marketing as a part of the holistic marketing concept, which consists of four main components: relationship marketing, integrated marketing, internal marketing, and socially responsible marketing. In times of intense global competition, a customer-oriented business policy belongs among the fundamental preconditions for business success. "Customer relationship management embraces employees, business processes and IS/IT technology with the aim to maximise customer loyalty and to consequently increase the company's profitability. It is a part of corporate strategy and as such, it becomes a part of corporate culture. In terms of technology, it makes use of the potential and the possibilities offered by the Internet more increasingly." [5, p. 18] Customer relationship management (CRM) comprehends a process ranging from customer acquisition (CCM Customer Creation Management) and retention (CRM) to customer churn (CTM - Customer Termination Management). One of the essential objectives in business is to achieve customer satisfaction at all levels. For the purposes of this article, its authors focus only on the "gap" between customer retention and customer churn (Fig. 1). First step to customer retention is their satisfaction with products of the company.

Although literature provides a general definition of satisfaction, the authors of this article believe that there are several levels of satisfaction. The first level may be considered as simple satisfaction. The second level represents the willingness to recommend the product or service to others (fidelity). The highest and most valuable level is loyalty when the customer willingly recommends the product or service to others and returns. In this case lordache a Sirbu [12] use the term customer enthusiasm. Kotler and Keller [15] define satisfaction as "the level of satisfaction of a customer's expectations that is linked to how the customer perceives and values the purchased product". The Czech Technical Standard CSN EN ISO 9000:2006 


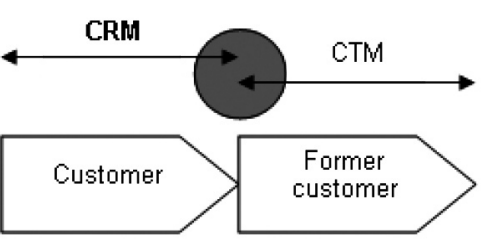

Source: Own diagram according to Lehtinen [17]

defines the term "as a customer's opinion on the level to which a business case fulfilled the customer's needs and expectations". More authors, e.g. Moon-Koo, Myeong-Cheol, DongHeon [23], mention a definition of satisfaction by Oliver: "Customer satisfaction generally means customer reaction to the state of fulfilment, and customer judgment of the fulfilled state." The same authors state that a high level of satisfaction increases the level of loyalty and that the main factor of satisfaction is the customer's own perception of the services quality. This view is also supported by McDougall and Levesque [19] who besides other industries monitored restaurants as well. These definitions are consistent with the Proposal of Spa Guest Satisfaction Model provided in Fig. 2. This proposed model shows some limits for guests on comprehensive and contributory spa stays, because some of their payments and their return rate are to a certain point regulated. An overview of loyalty definitions provide Szczepańska and Gawron. [29]

\section{Fig. 2: Proposal of Spa Guest Satisfaction Model}

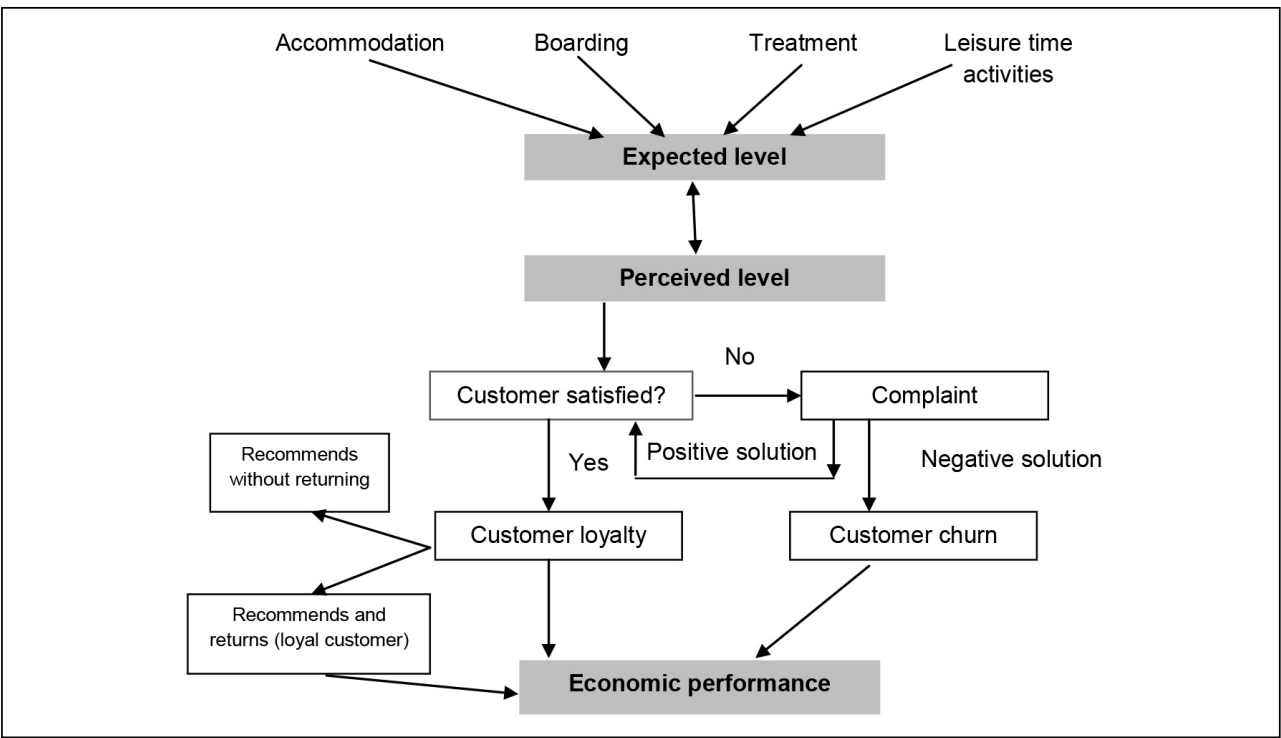


Satisfaction is closely linked with complaint (the customer's dissatisfaction with the rendered performance may lead to a complaint). Momberger (in [2]) associates complaint with the issue of quality and he puts both these areas in the foreground. The authors of this article deem that some definitions fail to state that if the complaining customer is satisfied (the complaint is resolved according to the customer's expectations), such customer becomes loyal to the particular company (see Fig. 2). Momberger's research shows that a company may reacquire an unsatisfied customer, provided, that it takes the customer's complaint seriously and attempts to resolve it as soon as feasible. There is a tolerance zone of complaint response, so called tolerance field, between the expected and acceptable response. If a standard acceptable response is not achieved, there is dissatisfaction because not even the minimum requirements of the customer based on the complaint were met. If the perceived complaint response is on the acceptable response level, the customer becomes disinterested or there is a low level of satisfaction with the response. According to Stauss ([9]), the following factors determine the level of expectation and tolerance zone's width: understanding of the customer's role, problem's relevance, perceived fault of the provider, explicit and implicit promise, experience with complaints, verbal communication, and expected response to the complaint. As mentioned in the introduction, differences may exist within individual diversities. The Czechs are generally denoted as frequent complainers, yet they go over to a new provider only exceptionally. The German customers who form a significant section of the Czech spa guests are fairly conservative. [11]

The issue of satisfaction also examine e.g. Stauss and Seidel [28], Kozel [16], Meffert, and Bruhn [20]. They focus on a comparison of the benchmarks and actual perception. The relationship between these two variables stands in the foreground and their comparison may result in three different situations: (1) perceived level > expected level; (2) perceived level = expected level; (3) perceived level < expected level.

The perceived level means the current state of the received service. Nonetheless, there is a difference between objective and subjective performance. While objective performance is the same for all customers, subjective performance is based on a variety of perceived effects that may differ with each customer. The existence of a large number of perceived performance levels for one state is no exception. The expected level expresses the customer's expectations in relation to the provided services. Literature often mentions various benchmarks (e.g. expectations, experience standards, or ideals). While expectations mainly concern the expected performance level, experience standards build on the experience of customers with the same or similar product or service. [14]

In addition, satisfaction may be viewed from several perspectives: Economical perspective: A customer makes a purchase under conditions that are consistent with the value of the service for the customer. One of the possible approaches envisaged by Simová [27] is the perception of value as a multidimensional concept, comprising both functional and affective dimensions. In this article, the economical perspective of satisfaction will be preferred. Psychological perspective: An essential role is played by emotions. Vysekalová [30] claims, "the conception, existence and satisfaction of needs as the base of motivation are intertwined with emotions, the satisfaction of a need always carries a positive emotional accent". Sociological perspective: It examines customer behaviour from the point of view of the environment in which the customer lives and the community with which the costumer associates.

\section{Selected Approaches to Measurement of Customer Satisfaction and Loyalty}

With the growing significance of customer satisfaction over the recent years, some countries have introduced national customer satisfaction indices (e.g. Switzerland Swiss Index of Customer Satisfaction). The development of these indices is recorded in an easy-to-understand way e.g. in Johnson et al. [13]. This type of indices provides a more in-depth understanding of the relationship between the customer and the company with the aim to acquire findings that would aid in the planning and implementation of improved company satisfaction programs. Each of these models presents a uniform overview of customer preferences in terms of the quality of products and services. Although the Czech Republic has 
no established quality control system at present, certain areas have been making use of specific standards (e.g. gastronomy - HACCP system, accommodation - uniform (non-compulsory) classification of accommodation facilities, etc.).

The objective of this article is to examine the customer satisfaction and loyalty index at the company level. "The principle of measuring customer satisfaction is based on measuring overall (accumulated) satisfaction, which is influenced by a wide range of partial, satisfaction-oriented factors. These factors need to be measurable and their significance (weight) for the customer with respect to overall satisfaction has to be known." [16, p. 190] Today, a variety of different methods and models [7] may be utilised to ascertain the level of customer satisfaction, such as Satisfaction Only method, Gap analysis, Importance-Satisfaction (I-S) model, Multiplicative approach, Customer Satisfaction Index. For the purposes of this article, the customer satisfaction index will be calculated with the aid of the adapted formula according to Foret [8]:

$$
C S I_{j}=\frac{\sum_{i=1}^{n} v_{i j} * x_{i j}}{4 \sum_{i=1}^{n} v_{i j}}
$$

$\mathrm{CSI}_{\mathrm{j}}$ - customer satisfaction index for the customer $j$,

$\mathrm{v}_{\mathrm{ij}}$ - weight of $i^{\text {th }}$ measurable variable for $j^{\text {th }}$ customer,

$\mathrm{x}_{\mathrm{ij}}$ - value of $i^{\text {th }}$ measurable variable for $j^{\text {th }}$ customer,

4 - relates to applied scale ( 1 to 4 scale),

$\mathrm{n}$ - number of measurable variables.

A term often mentioned in connection with customer satisfaction is loyalty. It represents a long-term process, a developing relationship between the service provider and the customer. A loyal customer is someone who becomes emotionally attached to a brand or a company. An important condition with respect to loyalty is customer retention. As regards the relationship between these two terms, we may say that satisfaction is opinion-based, while loyalty is a manifestation of consumer buying behaviour. The level of loyalty may be measured with the aid of the customer loyalty index. [18]

$$
C L I=C S I * C R I * S R I
$$

CLI - customer loyalty index,

$\mathrm{CSI}$ - customer satisfaction index,

$\mathrm{CRI}$ - customer retention index,

SRI - spontaneous recommendation index in relation to a company product or brand.

This index is in line for example with the model used by Oh [25] who studied the link between the perceived price, perceived quality, perceptions and customer satisfaction and the value which should then influence the intention of repeated purchase and intention of spontaneous recommendation (Oh refers to it as the Word-of-Mouth Communication intention). Yunus, Bojei and Rashid [32] chose a similar concept in studying the low-cost airlines' customers' loyalty. When the perceived services quality is understood as an independent variable implying the customer's satisfaction and subsequently also the customer loyalty. This article deals with loyalty specifically in the conditions of a spa enterprise, i.e. in the spa and medical tourism, characterised mostly by older clients who often repeat their visits. The cruise tourism studied by Petrick [26] has a similar customer characteristic. He also concluded that the customer satisfaction influences their loyalty and that the more loyal customers are more profitable for the enterprise in the end. Loyalty in the medical tourism industry was also studied by $\mathrm{Ho}$, Hsieh and $\mathrm{Yu}$ [10]. Mohajerani and Miremadi [22] in their hotel industry research also discovered a positive correlation between the value perceived, customer satisfaction and customer loyalty.

\section{Research of Customer Satisfaction and Loyalty in a Spa Company}

The objective of the research was to examine the possibilities of measuring loyalty and satisfaction of customers in a spa company based on comparably simple data collection. Partial objectives are (1) to set (compute) weights for different factors in customer satisfaction index; (2) to compute customer satisfaction index (CSI) and customer loyalty index (CLI); (3) to compare CSI for different customer segments; (4) to validate the set of items used for data collection.

\subsection{Research Methodology}

Development of a questionnaire research was the key to carrying out the study, or specifically the selection of factors (items) influencing the 
quality within the framework of the individual variables monitored: accommodation (U), boarding $(\mathrm{J})$, spa treatment $(\mathrm{L})$ and leisure time activities (K/S). The research took place in the following steps.

\subsubsection{Research Conducted among Other Spa Companies}

Sample questionnaires were collected and an online review of the websites of the subject spa companies was carried out. The objective of the review was to determine what factors the other spa companies focus on, what scales they use, and how their questionnaires are structured.

\subsubsection{Interviews with Spa Guests}

Customer opinions are the most valuable asset for any company. The authors have taken advantage of the opportunity to establish direct contact with customers in the form of focus group. The outcome of these interviews was the definition of factors and their items that are important for measuring the satisfaction. As mentioned in the introduction, the authors view customer groups as various diversities and thus the interviews differed depending on their nationality with respect to the customer structure of the spa company under review. Ten groups (each approximately with 10 participants: five groups with German guests and five groups with Czech guests) took part in the focus group. Those guests stayed at least one week in the spa company.

\subsubsection{Interviews with Experts}

From the point of view of the business managers from the other spa companies, customer satisfaction is important. Nonetheless, as the present times are not very favourable to balneology, everyone is more concerned about "numbers" than customer opinions. Naturally, inquiries among guests are conducted, yet the processing of the collected data is not ideal in many companies. The evaluations are rather simplified and the companies do not use any sophisticated model that would point to problematic areas. Within these interviews $(n=10)$, the importance of the individual variable studied (accommodation, boarding, spa treatment and leisure time activities) in the customer satisfaction evaluation for the spa companies business managers was studied. Stipulating the expert weights for the factors in the CSI and verification of factors and items important for satisfaction were the output of the questioning. Each expert had to weight four observed variables according to his perception, in total each expert's weights had to make up $100 \%$ in total. Experts' weights were averaged for each variable and mathematically rounded.

\subsubsection{Composition of Questionnaire}

Several key factors (items) were selected based on the previous steps for each variable (satisfaction determination factor) - see Fig. 2. The customers then evaluated 23 items on the scale of one through four (excellent-goodaverage-unsatisfactory). Factors represent the price dimension, technical quality and functional quality (mostly focusing on the staff attitude). The authors worked with the extended marketing services mix where the essential space is dedicated to the price, people, physical evidence, and process factors, as well as with the Grönroos' approach ([3]). In addition to conventional hotel accommodation, the questionnaire needed to encompass the area of provided therapeutic care (spa treatment) and leisure time activities. The authors looked at satisfaction mainly from the economic perspective.

The evaluation of the satisfaction/quality of the 23 defined items (Tab. 1) was a key part of the questionnaire. The ordinal data received was transformed into nominal data 1-2-3-4 that may resemble school grades. We believe the respondents understood it in a similar way because it is the simplest interpretation. A simple arithmetic mean was calculated from the responses in the individual areas. We got a vector of four values for each respondent, representing his or her evaluation of the four variables (factors).

The respondents were to evaluate their individual preference in the next question. They also filled in the importance $(1=$ the least important, $5=$ the most important) they attach to the individual factors $(\mathrm{U}, \mathrm{J}, \mathrm{L}$ and $\mathrm{K} / \mathrm{S}$ ). These customers' preferences were then used to establish the weights in the customer satisfaction index (CSI). The weight of the specific factor was calculated as the proportion of the value given to the factor and the total of all of the values given. We will thus get a vector of four values representing the weights for the four areas, with their total equalling one.

The vector of the values of the factors is multiplied scalarly by the weights vector, thus receiving an index (scalar value) representing 
Tab. 1: Questionnaire - factors and items of satisfaction

\begin{tabular}{|c|c|c|c|c|}
\hline \multicolumn{2}{|c|}{ U-Accommodation } & \multirow{2}{*}{$\mathrm{J}$-Boarding } & \multirow{2}{*}{$L$ - Spa treatment } & \multirow{2}{*}{ K/S - Leisure Time activities } \\
\hline Front Desk & Room & & & \\
\hline U1 - Welcome & $\begin{array}{l}\text { U5 - Cleanliness } \\
\text { and cleaning }\end{array}$ & J1 - Menu quality & L1 - Medical examination & $\begin{array}{l}\text { K1 - Offer of cultural events } \\
\text { and excursions }\end{array}$ \\
\hline $\begin{array}{l}\text { U2 - Information } \\
\text { upon arrival }\end{array}$ & $\begin{array}{l}\text { U6 - Technical } \\
\text { condition }\end{array}$ & J2 - Menu variety & L2 - Procedures & $\begin{array}{l}\text { K2 - Quality and scope } \\
\text { of provided information }\end{array}$ \\
\hline U3 - Professionalism & U7-Comfort & J3 - Service & L3 - Equipment & $\begin{array}{l}\text { K3 - Approach of personnel } \\
\text { of infocentre }\end{array}$ \\
\hline \multirow[t]{2}{*}{$\begin{array}{l}\text { U4 - Complaisance } \\
\text { and helpfulness }\end{array}$} & U8 - Price/quality & J4 - Price & L4 - Hygiene & $\begin{array}{l}\text { K4-Opening hours } \\
\text { of infocentre }\end{array}$ \\
\hline & & $\mathrm{J} 5$ - Atmosphere & L5 - Approach of personnel & S - Aquacentre \\
\hline
\end{tabular}

Source: own

the given customer's satisfaction. In the end the index is aligned to norm so that its highest value is 1 (the respondent answered all 23 questions as "excellent") and the lowest value 0 (all 23 questions were answered as "unsatisfactory"). The index can also be understood as a percentage fulfilment of the enterprise's goal: value 1 is a $100 \%$ satisfied customer etc.

It was necessary to add two more questions into the questionnaire to allow the calculation of $\mathrm{CRI}$ and $\mathrm{SRI}$ in order to calculate the loyalty index (CLI):

$\mathrm{CRI}$ - Will you use the services of our hotel during your next visit? (yes $=1$, no $=0$ );

SRI - Will you recommend the services of our hotel to others? (yes $=1, \mathrm{no}=0$ ).

The customer loyalty index is then calculated as the product of the customer satisfaction index and two binary variables (resp. CRI and SRI). The resulting value of the loyalty index for individual customer can thus be either the same as the satisfaction index, or zero. It can be expected that the zero loyalty index is tied to the visitors with a rather low satisfaction index.

The last part of the questionnaire was composed of answers to the segmentation questions, which would allow monitoring CSI, CLI for different company customers segments. The segmentation criteria included gender, type of stay, type of accommodation (hotel), nationality, age and number of visits.

\subsubsection{Questionnaire Survey}

A draft questionnaire was prepared for a pilot survey conducted at three different spa companies in 2011. Subsequently, the questionnaire was modified according to the obtained results and distributed in the company under review in the years 2012 and 2013. The survey targeted spa guests who had stayed at one of the spa hotels operated by the spa company during this period. The questionnaire is distributed upon arrival at the reception and it is available to the guests upon their request at any time during their stay. In order to motivate the guests to complete the form, it includes a competition draw for a weekend stay. In total, we received 7,442 questionnaires, which is a relatively big sample that allowed us to calculate the CSI and CLI. This sample covers approximately $9 \%$ of all guests of the company. The sample is proportional regarding the different types of stays in the company as well as age structure of the customers (compared to the basic set, the total number of all customers in the reviewed company). Nevertheless, the structure of respondents regarding each hotel of the company and the nationality of the guests is not proportional, so those results have to be handled with care. Yet, still the sizes of each observed group of respondents are broad enough to achieve applicable results. Validation of the questionnaire is performed in the chapter 4.4.

\section{Research Findings}

In this chapter, you will find our main research findings. All calculations have been made with the Matlab software, which made it possible to analyse the sample data in high detail. 


\subsection{Customer Satisfaction Index - Setting the Weights for Different Factors}

When calculating the customer satisfaction and loyalty indices, the authors of this article deal with the issue whether the different levels of importance of the individual components (factors) of the spa stay (spa treatment, boarding, accommodation, leisure time activities) influence the overall customer satisfaction/loyalty calculations. One of the partial objectives is to determine, which area and what factors are important for the particular customer. Moreover, whether a change in the level of satisfaction with sub-areas could result in a change of the overall satisfaction.

\section{Fig. 3: Histogram (empirical density) of the CSI, index variance with use of computed weights}

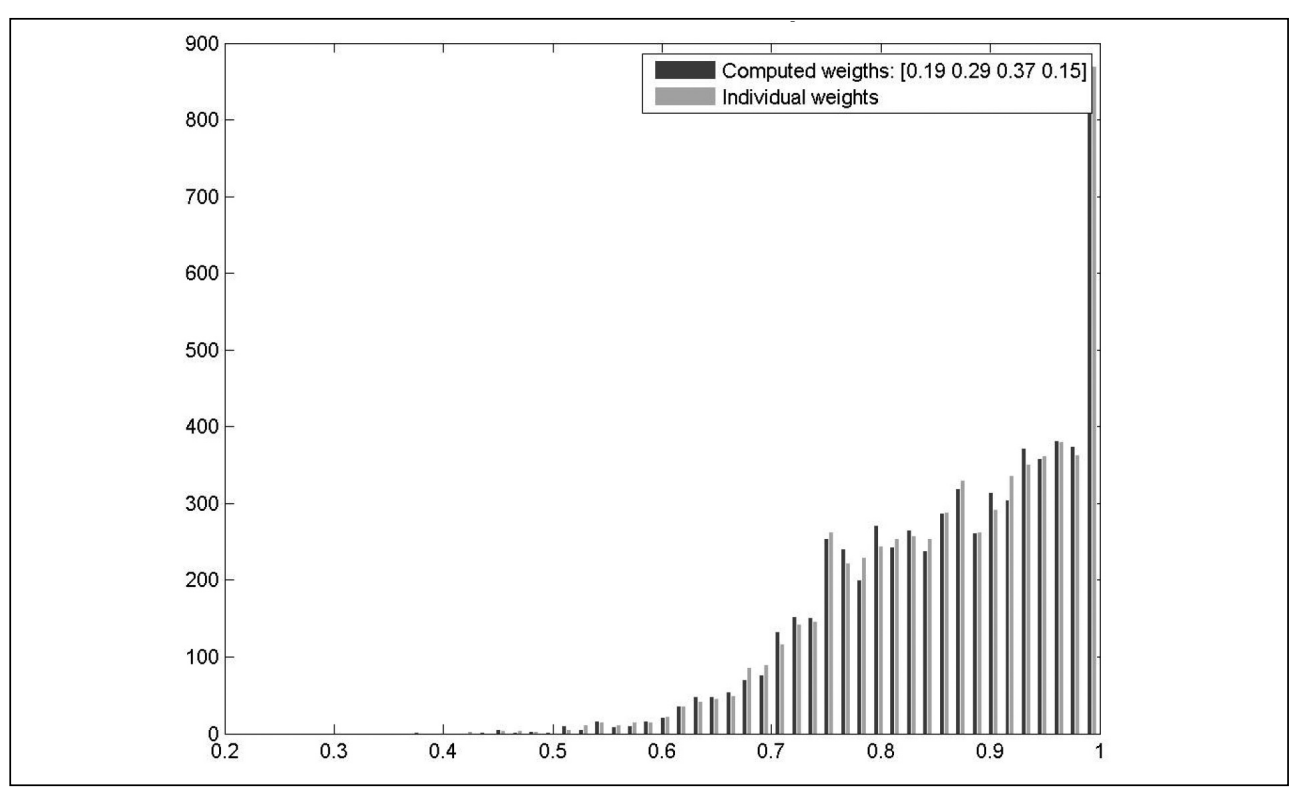

An important task was to define the method of determining the weights of the examined factors. The authors decided to inquire into five methods of weight determination: (1) all areas are equally important (for comparison purpose); (2) individual guest opinions from the questionnaire survey (there is a different CSI for each customer); (3) average of the individual guest opinions; (4) expert opinion (based on interviews with experts - spa company managers); (5) calculated weights (based on the sample).

For the purpose of further calculations we prefer to work with the whole set of calculated $\mathrm{CSI}_{\mathrm{i}}$ at the same time rather than with selected descriptive characteristics (e.g. average, median, variance) only. This empirical function of density, or histogram of absolute frequency, is presented in Fig. 3.

Let us consider a questionnaire where the respondents would not fill in the importance of the individual areas and we would not thus have individual weights of each respondent available. In such case, we would have to use arbitrary weights. The use of the so-called expert weights seems to be suitable, i.e. weights set up by experts with knowledge of the respective industry. The expert weights were set up based on interviews with the spa enterprises managers as accommodation 0.25 , boarding 
0.10 , spa care 0.50 , culture and sports 0.15 . If we replace the individual weights given by the respondents with these weights, we can test if the resulting function densities correspond or not. According to Kolmogorov-Smirnov test $(\alpha=0.05)$ we cannot reject the zero hypothesis about the correspondence of these distributions, so statistically both density functions come from the same population. The expert weights thus seem to be set up well and they do not influence the resulting customer satisfaction index. The $\mathrm{P}$-value of the given test is close to the limit of 0.05 , though. The same result came also from Cramér-von-Mises two samples test. So we can state that the distribution functions of $\mathrm{CSI}_{\text {for }}$ weights set by experts and weights of individual customers do not differ, $\alpha=0.05$. This was proofed also for all different segments we researched.

Instead of expert weights, there is the option of trying to calculate such weights, which would generate the density function as close as possible to the empirical function from Fig. 3. All possible combinations of weights with accuracy of 0.01 (total of 167,002 combinations) were tested for this purpose and the result with the highest $\mathrm{P}$-value of Kolmogorov-Smirnov test was selected. The calculated weights of accommodation 0.19 , boarding 0.29 , spa care 0.37 , leisure time activities 0.15 generate the customer satisfaction index distribution, which seems to best resemble the empirical density function of this index (see Fig. 3). It is therefore obvious that the "expert weights" significantly underestimate the importance of boarding and overestimate the spa treatment importance on the other hand. These data suggest that the spa company managers neglect boarding and primarily focus on the therapeutic services and accommodation. It can be explained in such a way that the customers consider the spa care and the treatment related to it as a "matterof-fact", and on the other hand, they want to "enjoy" the hospitality services. Let us add for completeness that if we use equal weights $(\mathrm{U}-0.25, \mathrm{~J}-0.25, \mathrm{~L}-0.25, \mathrm{~K} / \mathrm{S}-0.25)$ the result of Kolmogorov-Smirnov test will have P-value 0.00003. Therefore, these weights generate completely different distribution in the customer satisfaction index than the empirical distribution. We may therefore conclude that when determining the spa guest CSI, the same importance cannot be assigned to all examined areas.

The last possible way of deciding the weights is the utilization of the individual respondents' weights average.

From the point of view of future prosperity of the spa enterprise, it is important to have an overview of the customers' preferences according to the different types of stay and the number of stays in the past. It is obvious from Tab. 2 that we find differences in the areas of importance of individual factors influencing satisfaction between the individual segments.

\section{Tab. 2: Computed weights of examined factors for different segments}

\begin{tabular}{l|c|c}
\multicolumn{1}{c|}{ Type of stay/number of stays } & $\mathbf{n}$ & Computed weights (U-J-L-K/S) \\
\hline spa - comprehensive & 992 & $0.26-0.27-0.35-0.12$ \\
\hline spa - contributory & 284 & $0.17-0.26-0.39-0.18$ \\
\hline spa - self-payers & 4,430 & $0.17-0.35-0.33-0.15$ \\
\hline wellness & 1,161 & $0.27-0.27-0.34-0.12$ \\
\hline hotel & 672 & $0.26-0.29-0.31-0.14$ \\
\hline first stay & 3,505 & $0.23-0.25-0.38-0.14$ \\
\hline $2 x-5 x$ & 2,301 & $0.17-0.23-0.41-0.19$ \\
\hline $6 x-10 x$ & 1,014 & $0.2-0.31-0.34-0.15$ \\
\hline $10+$ & 795 & $0.3-0.32-0.28-0.1$ \\
\hline
\end{tabular}


The most numerous group of visitors from the point of view of stay, i.e. the self-paying clients, put the greatest emphasis on boarding (the weight of boarding is 0.35). Therefore, we can see the largest opportunity for improving the satisfaction index here. This is also confirmed by the increase in the weight of boarding for the visitors who have gone through five or more visits, along with the decrease of the spa treatment's importance. With the repetition of the stay the customers seem to put greater emphasis on other factors (they consider the rest as "met").

To conclude, we can state that the management of a spa company might choose the weights of experts, the computed weights or the averaged individual weights for their computation of CSI and further for CLI. However, it is important to choose one set of weights and use it in the long term so that the computed values stay comparable. It seems evident once again that the management of spa companies underestimates the importance of boarding and overestimates the importance of spa facilities for customer satisfaction. This does not say that spa facilities are not important. More likely, it means that customers are anticipating that spa facilities in a spa company are on a very high level so they put more emphasis on boarding (catering) in their decision process than expected.

\subsection{Computed CSI and CLI}

Although the difference between CSI a CLI computed with help of different weights (see Tab. 3 ) is not extreme, statistical differences were proofed. Overall the average difference between $\mathrm{CSI}$ and $\mathrm{CLI}$ is from 2 to $4 \%$ (CLI is always lower). It seems to be helpful to confront the results of the customer satisfaction index and the customer loyalty index. (see Fig. 4 and Tab. 4).

\section{Tab. 3: Computed overall CSI and CLI for different weights}

\begin{tabular}{l|c|c|c|c}
\multicolumn{1}{c|}{ Index / Weights } & Individual & Equal & Expert & Computed \\
\hline CSI & $86.52 \%$ & $85.92 \%$ & $86.87 \%$ & $86.54 \%$ \\
\hline CLI & $83.82 \%$ & $83.23 \%$ & $84.07 \%$ & $83.85 \%$ \\
\hline
\end{tabular}

\section{Fig. 4: Comparison between empirical density function of CSI and CLI=0}
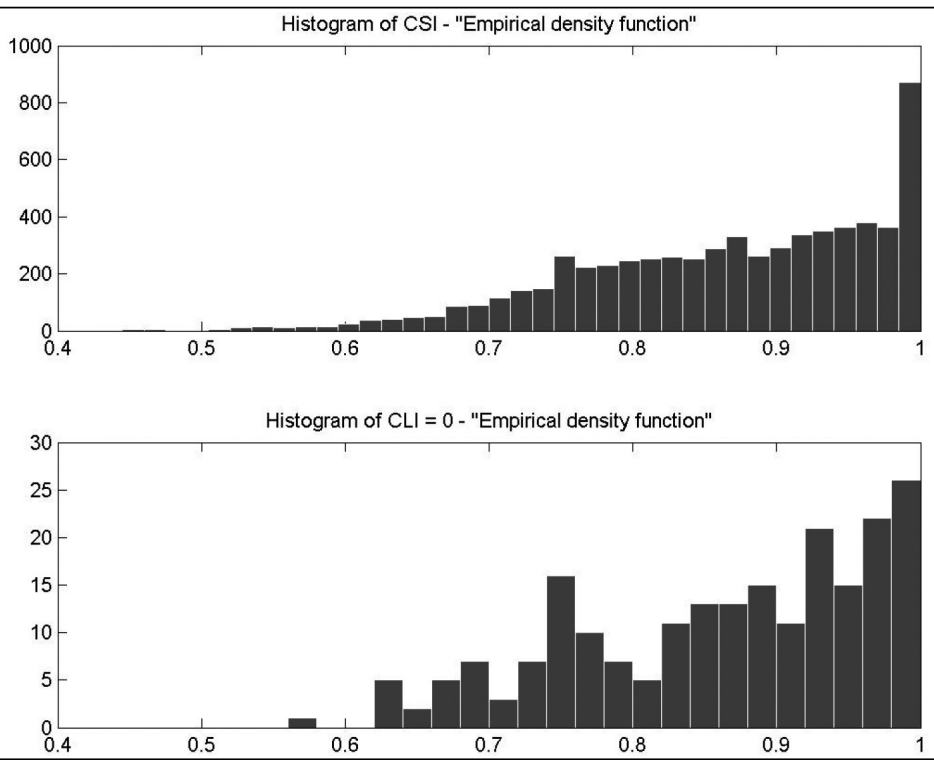
The above clearly shows that spa companies should pay detailed attention to the acquired data and they should adjust their business plans according to the analysis results. We investigated the share of the customers with a zero CLI as well as the CSI value for such customers (they should have lower CSI values) based on these results. It seems to be obvious that high CSI level does not necessarily mean high level of CLI. The share of the customers with zero loyalty indices is important for the company. The overall share of such customers is 0.0462 , i.e. just below $5 \%$. This share, by different segments, is presented in Tab. 4. The decreasing share of zero value in the satisfaction index with the increasing number of visits can be evaluated positively. The company is able to maintain the loyalty of its customers. On the other hand, it is obvious and logical as well that the hotel-stay clients are the least loyal as well as the guests who visited the company for the first time. One possible explanation is that the customers look up another destination for their next stay even in the case of complete satisfaction. This is called variety seeking behaviour - e.g. Horbel and Woratschek [31].

\section{Tab. 4: Shares of $C \mathrm{Cl}_{\mathrm{j}}=0$ for different segments}

\begin{tabular}{l|c|c}
\multicolumn{1}{c|}{ Type of stay/number of stays } & $\mathbf{n}$ & Share of CLI $_{\mathbf{i}}=\mathbf{0}$ \\
\hline spa - comprehensive & 992 & 0.0441 \\
\hline spa - contributory & 284 & 0.0286 \\
\hline spa - self-payers & 4,430 & 0.0413 \\
\hline hotel & 672 & 0.0396 \\
\hline wellness & 1,161 & 0.0758 \\
\hline first visit & 3,505 & 0.0645 \\
\hline $2 x-5 x$ & 2,301 & 0.0358 \\
\hline $6 x-10 x$ & 1,014 & 0.0282 \\
\hline $10+$ & 795 & 0.0288 \\
\hline Czech & 4,716 & 0.0411 \\
\hline German & 2,965 & 0.0537 \\
\hline
\end{tabular}

Source: own

\subsection{Computed CSI for different segments - ANOVA}

As mentioned in the questionnaire we used several segmentation questions (e.g. type of visit, different hotels, nationality) which allow us to compute CSI for different segments and compare their values and distribution functions. The average values of CSI and CLI seemed to be different, so we proofed them with ANOVA analysis and confirmed that they are not equal for $\alpha=0.05$ (Fig. 5).

It seems to make sense - from the manager's point of view - to compare CSI for different segments separately. For our sample, the following implications were found:

The guests give different evaluation according to their nationality - the Czechs are more positive and satisfied than Germans (by about $10 \%)$. The reasons can be seen especially in the stay type (the Czech guests come usually to stays paid by the health insurance company, the German guests usually pay for the whole stay themselves so their expectations are higher); and in the number of repeated stays (the German clients come repeatedly and they know what they should expect so the tolerance field narrows down). The guests evaluate individual hotels in a different way but two groups can be established $\left(3^{*}\right.$ hotels and $4^{*}$ hotels). Some differences can be found in the evaluation based on age. The greatest demands are presented by guests over 66 years of age. This might be caused by the fact that they place significant emphasis on their health, they know what they want and what they should expect and their tolerance field is quite narrow. The guests 


\section{Fig. 5: CSI for different segments ANOVA}

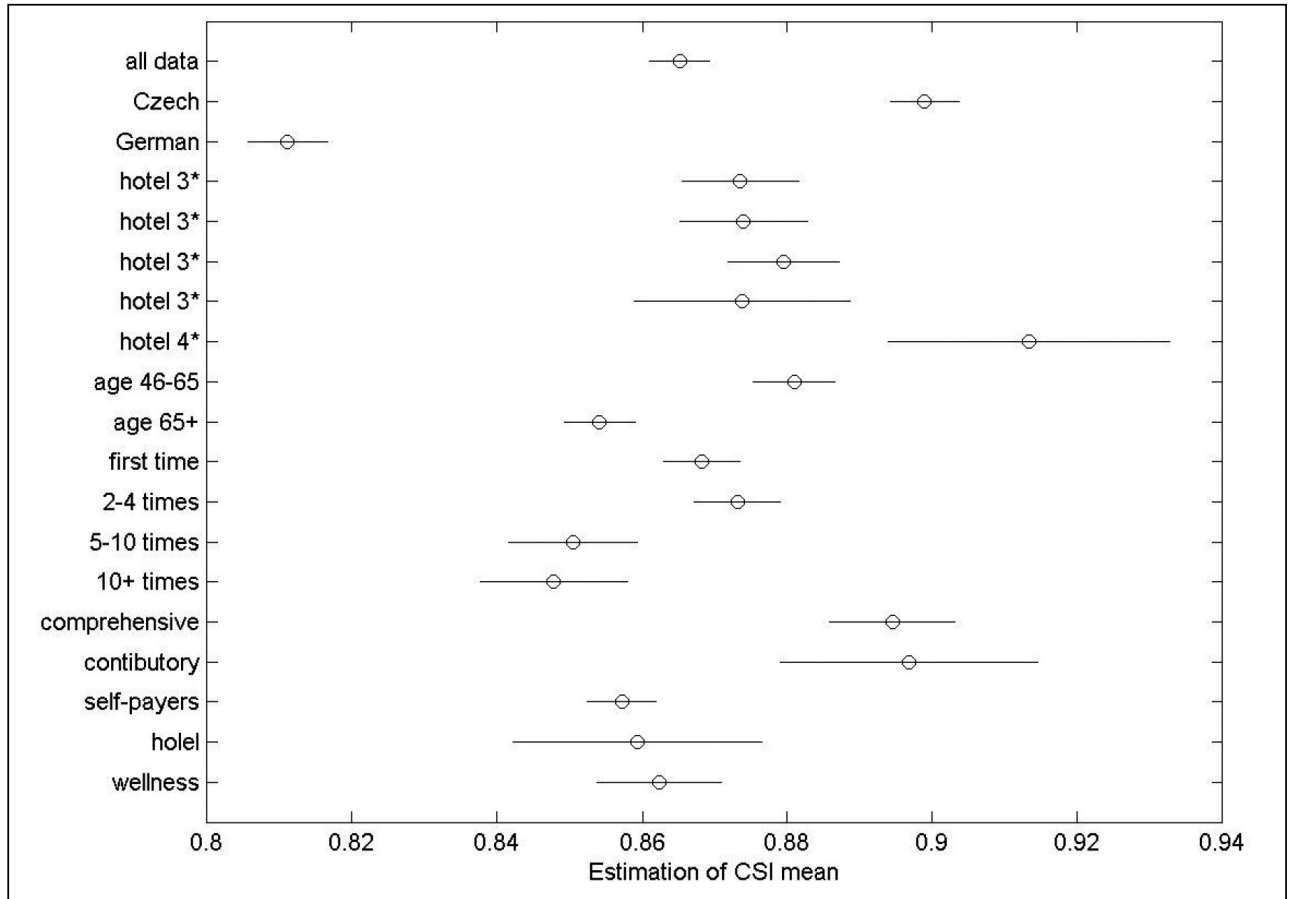

Source: own

aged 46-65 who begin to experience some health problems in their productive age and any improvement of their health (even though it may not be significant) somehow increases their satisfaction, or widens their tolerance field. The other age groups evaluate in a similar way.

The narrowest satisfaction tolerance field (and thus the lowest CSI) is seen in the guest groups, who keep returning to the spa facility - again they have a clear idea and they know what to expect and they want to get it. The other groups (up to 4 visits) evaluate in a similar way. There are significant differences within the individual types of stay. This is caused by the fact that the spa establishments focus usually on provision of treatment stays so wellness stays guests, accompanying persons or hotel accommodation guests do not show such a level of satisfaction as the other guests. On the opposite end are the guests whose stay is the health insurance covers. The self-paying guests are in the average CSI values - they know what they order for their money and expect to get it they are realists.

\subsection{Validation of the Questionnaire}

Besides the processing of the data acquired through the questionnaire survey, it is also necessary to carry out a "check" in the sense of reliability and validity. We will use the results of the correlation table, factors analysis and Cronbach's alpha for this purpose. The correlation table of answers to the individual questions is presented in Fig. 6. It is coloured so that the correlation coefficient equalling 1 is represented by the number 100 and the black colour, while the correlation coefficient equalling 0 is represented by 0 and the white colour. No correlation coefficient was negative. 


\section{Fig. 6: Correlation matrix for individual items of satisfaction}

\begin{tabular}{|c|c|c|c|c|c|c|c|c|c|c|c|c|c|c|c|c|c|c|c|c|c|c|c|}
\hline U1 & 100 & 68 & 61 & 64 & 29 & 26 & 27 & 21 & 27 & 25 & 25 & 17 & 30 & 8 & 10 & 12 & 15 & 15 & 11 & 16 & 11 & 15 & 15 \\
\hline U2 & 68 & 100 & 65 & 59 & 31 & 29 & 29 & 22 & 26 & 25 & 25 & 17 & 28 & 11 & 13 & 14 & 16 & 16 & 15 & 19 & 12 & 17 & 17 \\
\hline U3 & 61 & 65 & 100 & 66 & 31 & 31 & 33 & 25 & 31 & 28 & 28 & 20 & 33 & 10 & 14 & 18 & 18 & 18 & 14 & 19 & 13 & 16 & 20 \\
\hline U4 & 64 & 59 & 66 & 100 & 31 & 26 & 26 & 20 & 29 & 27 & 28 & 14 & 31 & 10 & 12 & 15 & 17 & 19 & 12 & 17 & 11 & 16 & 15 \\
\hline U5 & 29 & 31 & 31 & 31 & 100 & 38 & 35 & 24 & 24 & 24 & 23 & 13 & 23 & 10 & 15 & 16 & 19 & 18 & 9 & 12 & 9 & 16 & 13 \\
\hline 16 & 26 & 29 & 31 & 26 & 38 & 100 & 64 & 35 & 21 & 21 & 19 & 15 & 25 & 3 & 10 & 16 & 16 & 11 & 9 & 11 & 7 & 13 & 12 \\
\hline U7 & 27 & 29 & 33 & 26 & 35 & 64 & 100 & 43 & 22 & 22 & 17 & 18 & 24 & 3 & 9 & 14 & 14 & 10 & 9 & 11 & 7 & 15 & 13 \\
\hline U8 & 21 & 22 & 25 & 20 & 24 & 35 & 43 & 100 & 21 & 20 & 18 & 43 & 23 & 9 & 13 & 19 & 18 & 14 & 15 & 17 & 16 & 17 & 14 \\
\hline J1 & 27 & 26 & 31 & 29 & 24 & 21 & 22 & 21 & 100 & 82 & 60 & 34 & 58 & 17 & 22 & 24 & 25 & 24 & 20 & 21 & 15 & 21 & 21 \\
\hline $\mathrm{J} 2$ & 25 & 25 & 28 & 27 & 24 & 21 & 22 & 20 & 82 & 100 & 60 & 32 & 57 & 20 & 23 & 24 & 25 & 22 & 22 & 21 & 18 & 21 & 19 \\
\hline J3 & 25 & 25 & 28 & 28 & 23 & 19 & 17 & 18 & 60 & 60 & 100 & 29 & 60 & 17 & 21 & 22 & 26 & 23 & 17 & 18 & 13 & 20 & 14 \\
\hline $\mathrm{J} 4$ & 17 & 17 & 20 & 14 & 13 & 15 & 18 & 43 & 34 & 32 & 29 & 100 & 39 & 16 & 14 & 21 & 20 & 14 & 26 & 26 & 30 & 24 & 23 \\
\hline J5 & 30 & 28 & 33 & 31 & 23 & 25 & 24 & 23 & 58 & 57 & 60 & 39 & 100 & 15 & 20 & 25 & 25 & 21 & 21 & 24 & 18 & 22 & 17 \\
\hline L1 & 8 & 11 & 10 & 10 & 10 & 3 & 3 & 9 & 17 & 20 & 17 & 16 & 15 & 100 & 55 & 53 & 50 & 48 & 39 & 36 & 36 & 25 & 13 \\
\hline L2 & 10 & 13 & 14 & 12 & 15 & 10 & 9 & 13 & 22 & 23 & 21 & 14 & 20 & 55 & 100 & 77 & 80 & 83 & 27 & 29 & 22 & 24 & 15 \\
\hline L3 & 12 & 14 & 18 & 15 & 16 & 16 & 14 & 19 & 24 & 24 & 22 & 21 & 25 & 53 & 77 & 100 & 80 & 72 & 29 & 31 & 25 & 27 & 17 \\
\hline L4 & 15 & 16 & 18 & 17 & 19 & 16 & 14 & 18 & 25 & 25 & 26 & 20 & 25 & 50 & 80 & 80 & 100 & 81 & 27 & 30 & 23 & 26 & 17 \\
\hline L5 & 15 & 16 & 18 & 19 & 18 & 11 & 10 & 14 & 24 & 22 & 23 & 14 & 21 & 48 & 83 & 72 & 81 & 100 & 25 & 28 & 19 & 23 & 15 \\
\hline $\mathrm{K} 1$ & 11 & 15 & 14 & 12 & 9 & 9 & 9 & 15 & 20 & 22 & 17 & 26 & 21 & 39 & 27 & 29 & 27 & 25 & 100 & 80 & 59 & 51 & 27 \\
\hline $\mathrm{K} 2$ & 16 & 19 & 19 & 17 & 12 & 11 & 11 & 17 & 21 & 21 & 18 & 26 & 24 & 36 & 29 & 31 & 30 & 28 & 80 & 100 & 58 & 58 & 29 \\
\hline $\mathrm{K} 3$ & 11 & 12 & 13 & 11 & 9 & 7 & 7 & 16 & 15 & 18 & 13 & 30 & 18 & 36 & 22 & 25 & 23 & 19 & 59 & 58 & 100 & 40 & 35 \\
\hline K4 & 15 & 17 & 16 & 16 & 16 & 13 & 15 & 17 & 21 & 21 & 20 & 24 & 22 & 25 & 24 & 27 & 26 & 23 & 51 & 58 & 40 & 100 & 25 \\
\hline $\mathrm{S}$ & 15 & 17 & 20 & 15 & 13 & 12 & 13 & 14 & 21 & 19 & 14 & 23 & 17 & 13 & 15 & 17 & 17 & 15 & 27 & 29 & 35 & 25 & 100 \\
\hline & U1 & U2 & U3 & U4 & U5 & U6 & U7 & U8 & $\mathrm{J} 1$ & $\mathrm{~J} 2$ & $\mathrm{~J} 3$ & $\mathrm{~J} 4$ & $\mathrm{~J} 5$ & L1 & $\mathrm{L} 2$ & L3 & L4 & L5 & $\mathrm{K} 1$ & $\mathrm{~K} 2$ & $\mathrm{~K} 3$ & $\mathrm{~K} 4$ & $S$ \\
\hline
\end{tabular}

Some "darker squares" can be identified in the figure, representing the higher correlation coefficients between the given items. The first such square is $\mathrm{U} 1-\mathrm{U} 4$, the second one is $\mathrm{J} 1-\mathrm{J} 5$, the third L1-L5 and the fourth K1-S. The value of the correlation coefficient in the first square is about 0.6 , in the second one also about 0.6 (except question $\mathrm{J} 4$ - price), in the third it is between 0.7 and 0.8 , and finally in the fourth one it is significantly lower, but still about 0.5 (except item S - aquacentre). It seems, from this point of view, that the questionnaire has been correctly structured into the individual factors (variables). The low correlation between the answers to the individual question in the sub-area "Room" show possible issues in accommodation, where some services lag behind others, e.g. cleanliness and cleaning.

A factors analysis (Fig. 7, Tab. 5) by individual areas (and sub-areas) of the questionnaire was carried out, too. The goal of the analysis was to find latent factors and use them for identification of the questions, which are "duplicated" in the questionnaire. We found solutions for two factors in three areas of the questionnaire (Tab. 5). In Fig. 7 we illustrate the areas of Boarding and Spa Care.

From the point of view of degrees of freedom, it is not possible to achieve a model with more than two factors from five questions. All three above-mentioned models have a low test $\mathrm{P}$-value though and we therefore reject the zero hypothesis about the existence of two factors. Nevertheless, we can still try to interpret the results obtained. The first step is naming the latent factors. It is obvious from the graphs that the questions $\mathrm{J} 1$ and $\mathrm{J} 2$ in the area of Boarding are closest to each other. They relate to the quality and variety of meals. We can see a big loading with the first latent factor and low loading with the second factor on them. In addition, the specific variance of both questions is relatively low. We can therefore recommend that these two questions are replaced with one and the 


\section{Fig. 7: Factor analysis for Boarding and Spa Care}
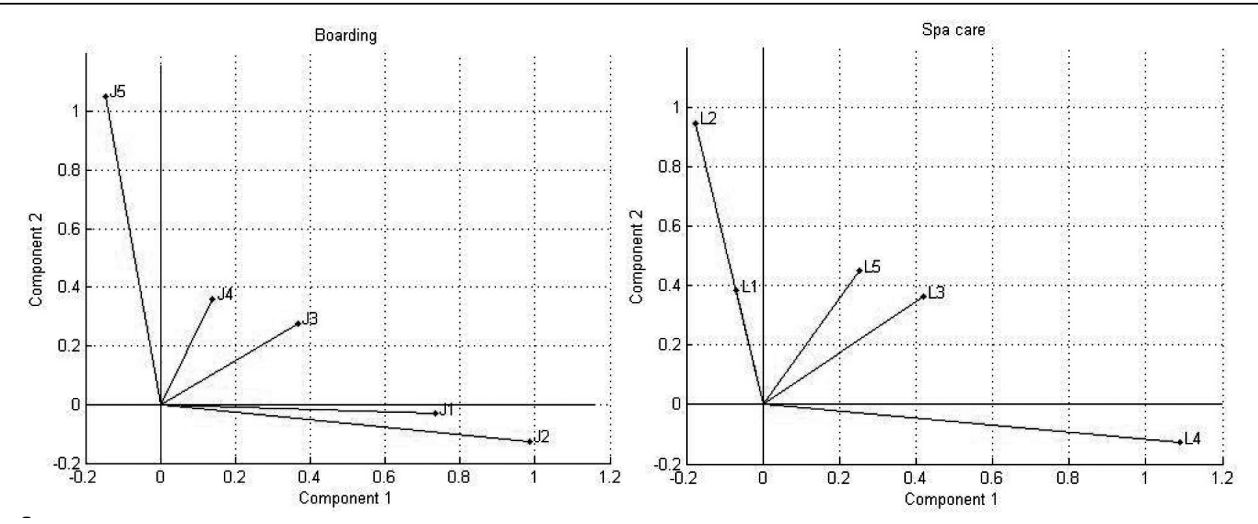

Source: own

Tab. 5: Factor analysis - boarding, spa care, leisure time activities

\begin{tabular}{|c|c|c|c|c|c|c|}
\hline Area & \multicolumn{2}{|c|}{ Boarding (J) } & \multicolumn{2}{|c|}{ Spa care (L) } & \multicolumn{2}{|c|}{$\begin{array}{l}\text { Leisure time activities } \\
\text { (K/S) }\end{array}$} \\
\hline P-value & \multicolumn{2}{|c|}{0.0016} & \multicolumn{2}{|c|}{$3.9729 \mathrm{e}-029$} & \multicolumn{2}{|c|}{$1.1594 \mathrm{e}-005$} \\
\hline $\begin{array}{l}\text { Name of the first component } \\
\text { (first latent factor) }\end{array}$ & \multicolumn{2}{|c|}{ Meals } & \multicolumn{2}{|c|}{$\begin{array}{l}\text { Environment the spa care } \\
\text { is provided in }\end{array}$} & \multicolumn{2}{|c|}{$\begin{array}{l}\text { Level of information } \\
\text { and information provisior }\end{array}$} \\
\hline $\begin{array}{l}\text { Name of the second component } \\
\text { (second latent factor) }\end{array}$ & \multicolumn{2}{|c|}{$\begin{array}{l}\text { Environment in which } \\
\text { is eaten }\end{array}$} & \multicolumn{2}{|c|}{$\begin{array}{c}\text { The spa treatment } \\
\text { procedures and medical } \\
\text { procedures }\end{array}$} & \multicolumn{2}{|c|}{ Activities themselves } \\
\hline \multirow{5}{*}{$\begin{array}{l}\text { Factor loadings matrix for the } \\
\text { individual questions in the } \\
\text { questionnaire }\end{array}$} & 0.7343 & -0.0298 & -0.0685 & 0.3832 & 0.1817 & 0.8076 \\
\hline & 0.9852 & -0.1253 & -0.1761 & 0.9454 & 0.5932 & 0.3238 \\
\hline & 0.3669 & 0.2768 & 0.4182 & 0.3618 & 0.5440 & 0.1415 \\
\hline & 0.1402 & 0.3607 & 1.0892 & -0.1292 & 0.6184 & -0.0585 \\
\hline & -0.1462 & 1.0528 & 0.2513 & 0.4483 & 0.3645 & -0.1217 \\
\hline \multirow{5}{*}{ Specific Variances } & \multicolumn{2}{|c|}{0.4897} & \multicolumn{2}{|c|}{0.889} & \multicolumn{2}{|c|}{0.1184} \\
\hline & \multicolumn{2}{|c|}{0.1819} & \multicolumn{2}{|c|}{0.3312} & \multicolumn{2}{|c|}{0.2864} \\
\hline & \multicolumn{2}{|c|}{0.6505} & \multicolumn{2}{|c|}{0.4615} & \multicolumn{2}{|c|}{0.5812} \\
\hline & \multicolumn{2}{|c|}{0.7815} & \multicolumn{2}{|c|}{0.0133} & \multicolumn{2}{|c|}{0.6625} \\
\hline & \multicolumn{2}{|c|}{0.0798} & \multicolumn{2}{|c|}{0.5626} & \multicolumn{2}{|c|}{0.9117} \\
\hline Cronbach's alpha for area & \multicolumn{2}{|c|}{0.7395} & \multicolumn{2}{|c|}{0.7392} & \multicolumn{2}{|c|}{0.7372} \\
\hline \multirow{5}{*}{$\begin{array}{l}\text { Cronbach's alpha after leaving } \\
\text { the given question out }\end{array}$} & \multicolumn{2}{|c|}{0.7395} & \multicolumn{2}{|c|}{0.7392} & \multicolumn{2}{|c|}{0.7371} \\
\hline & & & & & & \\
\hline & & & & & & \\
\hline & & & & & & \\
\hline & & & & & & \\
\hline
\end{tabular}


vacant spot in the questionnaire can be filled with another price-related question that seem to be problematic, or a question regarding the waiting staff where the company can relatively easily change the quality. The Tab. 5 also depicts Cronbach's alpha for both the whole area and its value always after leaving out one question. Cronbach's alpha is for all questions within the values considered "adequate" and thus it confirms the previous result where leaving out one of the questions, J1 or J2, will not change the reliability of the questionnaire in the area of boarding.

Let us add, for completeness, that even though we were not able to find a suitable factor analysis model of the area of Accommodation nor its individual sub-areas, the reliability of this area/subarea is better than in the other areas (Cronbach's alpha is 0.8357 for the sub-area of Reception, 0.7537 for the sub-area of Room and 0.8359 for the whole Accommodation area which is considered a very good value). The validity of the questionnaire could be computed also for different customer segments individually, but this is out of scope of this paper. However, we recommend running this in the spa company.

\section{Evaluation and Conclusion}

Doing business in the spa sector is specific. The companies are influenced by the legislature about public health insurance, which is nowadays very volatile in the Czech Republic. However, the market effectiveness of the enterprise cannot be assessed only by the final market results. One of the important indicators for the company management are the customer satisfaction and loyalty indices. Especially the level of loyalty can be understood as a type of future business results prediction.

The main benefit of this research for the company should be a deeper and better identification of the customers, the knowledge of the critical points in the process of services provided and their subsequent optimization in such a way as to avoid economic loss. The importance for the company comes mostly in the area of stabilization of the customer relationship and their further development. Economic significance can be seen within the marketing and business activities - a satisfied and returning customer who will share his or her positive (as well as negative) experience with other people in their social environment (word of mouth) is the best advertisement for the least money. Nevertheless, our article showed that sometimes the marketing experts' beliefs are different from customer expectations. The results of the computations showed, that even a small difference in total number (value of index) could be statistically significant and have important marketing and business consequences.

The results suggest that the guests of the spa company under review are satisfied and loyal (the value of the calculated indices always exceeds $80 \%$ ). The research was carried out only in one spa company and under the conditions prevailing in the Czech Republic (they might differ from other EU countries). However, the results show significant differences in satisfaction of different customer segments, e.g. Germans are less satisfied than Czechs are, self-payers are less satisfied than those guests on a stay, which is at least partially covered by public health insurance. Still the proposed model of spa guest satisfaction needs to be examined and tested for further use in other companies.

Following an in-depth examination, the authors of this article arrived at the conclusion that the questionnaires in use (or the data gathered) should be segmented at least according to the specific spa hotel and type of stay. The authors deem that categorisation into spa treatment and other stays would be sufficient since each of these groups has different priorities, interests and preferences. Nonetheless, such verification goes beyond the objectives of this article and the authors therefore recommend a more detailed research of the individual factors and their interrelationships.

The authors were nevertheless able to discover possible and suitable weights for the CSI (and CLI) calculation. The developed questionnaire seems to establish the spa company customers' satisfaction level in a consistent way. The premise that the spa facilities customers are rather diverse and their satisfaction differs in relation to their nationality, type of stay, age structure or repeated visits was met. The resulting values of the CSI and CLI - regardless of the way of establishing the weights - are high. However, it is obvious from the computed outputs that mere comparison of the resulting CSI and CLI is not adequate for effective management of 
the customers' relationships, and that even the small differences in the resulting values can be statistically significant.

It is obvious that even with the use of a rather simply structured data we can obtain essential information about the customers and their satisfaction and loyalty. This knowledge then contributes to setting up a suitable longterm work system with the customers and their repeated visits. We proofed, that even an easy questionnaire brings useful information for business decisions and can disprove some management assumptions.

The paper was elaborated in connection with solution of the research projects of the Faculty of Economics, University of West Bohemia, No. SGS-2014-047 and No. SGS-2013-063.

\section{Refernces}

[1] BLÁHA, E. České lázně v čase změn [online]. Praha: Senát PČR, 2013 [cit. 2014-0309]. Available from: http://www.senat.cz/xqw/ webdav/pssenat/original/70055/58847.

[2] BRUHN, D., STRAUS, B. Dienstleistungsqualität. Konzepte-Methoden-Erfahrungen. 2. Aufl., Wiesbaden: Gabler, 1995. ISBN 3309236554.

[3] CORSTEN, H., GÖSSINGER, R. Dienstleistungsmanagement. 5. Aufl. München, Wien: R. Oldenbourg Verlag, 2007. ISBN 978-3486-58237-6.

[4] Department of Health. Situace $v$ českém lázeňství [online]. Praha: MZCR, 2013 [cit. 2014-05-24]. Available from: http://osz.cmkos. cz/files/Article/447/TextDocument/materialministerstva-zdravotnictvi-pro-vladu---situacev-ceskem-lazestvi----cerven-2013.pdf.

[5] DOHNAL, J. Řízení vztahů se zákazníky procesy, pracovníci, technologie. Praha: Grada, 2002. ISBN 80-247-0401-3.

[6] EGER, L., INDRUCHOVÁ, Z. Diversity Management-Perceptions and Attitudes by Czech Managers. E+M Ekonomie a Management. 2014, Vol. 17, Iss. 1, pp. 73-81. ISSN 1212-3609. doi:10.15240/tul/001/2014-1-006.

[7] FONTENOT, G., HENKE, L., CARSON, K. Take Action On Customer Satisfaction. Quality Progress. 2005, Vol. 38, Iss. 7, pp. 40-47. ISSN 0033-524X.

[8] FORET, M., STÁVKOVÁ, J. Marketingový výzkum. Jak poznávat své zákazníky. Praha: Grada, 2003. ISBN 80-247-0385-8.

[9] HINTERHUBER, H. H., MATZLER, K. (Eds.). Kundenorientierte Unternehmensführung.
Kundenorientierung-KundenzufriedenheitKundenbindung. 6. Aufl. Wiesbaden: Gabler, 2009. ISBN 978-3-8349-1026-4.

[10] HO, Y. C., HSIEH, M. J., YU, A. P. Effects of Customer-value Perception and Anticipation on Relationship Quality and Customer Loyalty in Medical Tourism Services Industry. Information Technology Journal. 2014, Vol. 13, Iss. 4, pp. 652-660. ISSN 1812-5638. doi:10.3923/ itj.2014.652.660.

[11] HOVORKA, J. Češi si rádi a hodně stěžují, ale ke konkurenci jdou výjimečně [online]. Praha: Internet Info, 2011 [cit. 2014-05-23]. Available from: http://www.mesec.cz/clanky/ cesi-si-radi-a-hodne-stezuji-ale-ke-konkurencijdou-vyjimecne/. ISSN 1213-4414.

[12] IORDACHE, C-M., SîRBU, A. Customer loyalty - the guaranteed success of an organization on the market. Management Strategies Journal. 2013, Vol. 22, Iss. 4, pp. 4148. ISSN 1844-668X.

[13] JOHNSON, M., GUSTAFSSON, A., ANDREASSEN, T. W., LERVIK, L., CHA, J. The evolution and future of national customer satisfaction index models. Journal of Economic Psychology. 2001, Vol. 22, Iss. 2, pp. 217-245. ISSN 0167-4870.

[14] KLATOVÁ, E. Toleranční zóna spokojenosti zákazníků. In: Mezinárodní Batova konference pro doktorandy a mladé vědecké pracovníky. Zlín: UTB, 2010. pp.1-8. ISBN 978-80-7318-922-8.

[15] KOTLER, P., KELLER, K. L. Marketing management. Praha: Grada, 2007. ISBN 97880-247-1359-5.

[16] KOZEL, R., et al. Moderní marketingový výzkum. Praha: Grada, 2006. ISBN 80-2470966-X.

[17] LEHTINEN, J. Aktivní CRM Řízení vztahů se zákazníkem. Praha: Grada, 2007. ISBN 97880-247-1814-9.

[18] LOŠŤÁKOVÁ, H. Loajalita zákazníků a její řízení. Marketing a komunikace [online]. Praha: ČMS, 2007 [cit. 2011-03-09]. Available from: http://www.mandk.cz/view. php?cisloclanku=2007010022. ISSN 1211-5622. [19] MCDOUGAL, G., LEVESQUE, T. Customer satisfaction with services: putting perceived value into the equation. Journal of Services Marketing. 2000, Vol. 14, Iss. 5, pp. 392-410. ISSN 0887-6045.

[20] MEFFERT, H., BRUHN, M. Complaining behavior and satisfaction of consumers. In: DAY, R. L., HUNT, H. K. (Eds.). International fare in consumer satisfaction and complaining 
behavior. Bloomington: Indiana University: 1983, pp. 35-48.

[21] Ministry of Regional Development. Cestovní ruch v České republice 2012. Praha: MMR, 2013. ISBN 978-80-87147-44-3.

[22] MOHAJERANI, P., MIREMADI, A. Customer Satisfaction Modelling in Hotel Industry: A Case Study of Kish Island in Iran. International Journal of Marketing Studies. 2012, Vol. 4, Iss. 3, pp. 134-152. ISSN 1918-7203. doi:10.5539/ ijms.v4n3p134.

[23] MOON-KOO, K., MYEONG-CHEOL, P., DONG-HEON, J. The effects of customer satisfaction and switching barrier on customer loyalty in Korean mobile telecommunication services. Telecommunications Policy. 2004, Vol. 28, Iss. 2, pp. 145-159. ISSN 0308-5961.

[24] NENADÁL, J. Měření $v$ systémech managementu jakosti. Praha: Management Press, 2008. ISBN 80-7261-110-0.

[25] $\mathrm{OH}, \mathrm{H}$. Service quality, customer satisfaction, and customer value: A holistic perspective. International Journal of Hospitality Management. 1999, Vol. 18, Iss. 1, pp. 67-82. ISSN 0278-4319.

[26] PETRICK, J. F. Are loyal visitors desired visitors. Tourism Management. 2004, Vol. 25, Iss. 4, pp. 463-470. ISSN 0261-5177.

[27] SIMOVÁ, J. Customers' Store Attitudes and Store Loyalty in the Framework of Customer Value and CRM Performance. E+M Ekonomie a Management. 2006, Vol. 9, Iss. 4, pp. 120-134. ISSN 1212-3609.

[28] STAUSS, B., SEIDEL, W. Beschwerdemanagement. München: Carl Hanser Verlag, 2007. ISBN 3-446-40593-3. [29] SZCZEPAŃSKA, K., GAWRON, P.P. Changes in Approach to Customer Loyalty. Contemporary Economics. 2011, Vol. 5, Iss. 1, pp. 60-69. ISSN 1897-9254. doi:10.5709/ce.1897-9254.5.
[30] VYSEKALOVÁ, J., et al. Emoce $\checkmark$ marketingu. Praha: Grada, 2014. ISBN 97880-247-4843-6.

[31] WORATSCHEK, H., HORBEL, C. Are Variety Seekers Bad Customers? An Analysis of the Role of Recommendations in the Service Profit Chain. Journal of Relationship Marketing. 2006, Vol. 4, Iss. 3-4, pp. 43-57. ISSN 1533-2675. [32] YUNUS, N., BOJEI, J., RASHID, W. Service Quality towards Customer Loyalty in Malaysia's Domestic Low Cost Airline Services. International Journal of e-Education, e-Business, e-Management and e-Learning. 2013, Vol. 3, Iss. 4, pp. 333-336. ISSN 20103654. doi:10.7763/ijeeee.2013.v3.253.

Ing. Eliška Vildová University of West Bohemia Faculty of Economics

Department of Marketing, Trade and Services klatova@kmo.zcu.cz

JUDr. Ing. David Martinčík University of West Bohemia Faculty of Economics Department of Economics and Quantitative Methods martinci@kem.zcu.cz

Ing. Jan Tlučhoř, Ph.D. University of West Bohemia Faculty of Economics

Department of Marketing, Trade and Services jtluchor@kmo.zcu.cz

doc. Ing. Dagmar Jakubíková, Ph.D. University of West Bohemia Faculty of Economics Department of Marketing, Trade and Services jakubiko@kmo.zcu.cz 


\section{Abstract}

\section{MEASURING CUSTOMER SATISFACTION AND LOYALTY IN SPA COMPANIES}

\section{Eliška Vildová, David Martinčík, Jan Tlučhoř, Dagmar Jakubíková}

The importance of balneology for the economy of the Czech Republic has always been crucial. At a time of an unstable political environment as well as turbulent legislative and other changes, there is nothing more important than to ensure that spa guests are satisfied and that they return. Building customer loyalty and fidelity is a priority and today, it is one of the vital characteristics of modern marketing. A customer-oriented policy may become one of the keys to business success. The centre point of the issue under review is the difference between the expected and perceived level and its positioning in the tolerance zone of a particular customer. The main objective of the research is to examine the possibilities of measuring loyalty and satisfaction of customers in a spa company based on comparably simple data collection. The secondary objective is to point out the specific nature of providing spa services along with the factors that substantially influence the overall result of satisfaction and loyalty. The research results showed that managers and customers perceive the importance of satisfaction factors differently: customers put more stress on boarding than expected. As well as differences in levels of customer satisfaction and loyalty indices were proofed for different segments of customers. Therefore, the Czechs are in general more satisfied than Germans. Customers who come more often tend to be less satisfied. The guests, whose stay is at least partially covered by public health insurance, are more satisfied than self-paying customers. In general, it seems to be possible to obtain essential information about the customers and their satisfaction and loyalty from rather simply structured data gained with an easy questionnaire.

Key Words: Customer, health care, loyalty, satisfaction, spa care.

JEL Classification: M31, I11.

DOI: 10.15240/tul/001/2015-1-012 